\title{
Ortaokul Öğrencilerinin Bağlanma Stilleri ve Öz-Düzenleme Düzeyleri Arasındaki İlişkinin İncelenmesi
}

\author{
Ayşenur Baysal $^{1}$, Mustafa Özgenel ${ }^{2}$ \\ ${ }^{1}$ Sosyal Bilimler Enstitüsü, İstanbul Sabahattin Zaim Üniversitesi, İstanbul, Türkiye \\ ${ }^{2}$ Eğitim Fakültesi, İstanbul Sabahattin Zaim Üniversitesi, İstanbul, Türkiye
}

Sorumlu Yazar: Ayşenur Baysal, aysenurdayioglu@gmail.com

Makale Türü: Araştırma Makalesi

Kaynak Gösterimi: Baysal, A., \& Özgenel, M. (2019). Ortaokul öğrencilerinin bağlanma stilleri ve öz-düzenleme düzeyleri arasındaki ilişkinin incelenmesi. Eğitimde Kuram ve Uygulama, 15(2), 142-152. doi: 10.17244/eku.507650

\section{Investigation of the Relationship Between Secondary School Students' Attachment Styles and Self- Regulation Levels}

\author{
Ayşenur Baysal $^{1}$, Mustafa Özgenel ${ }^{2}$ \\ ${ }^{1}$ Graduate School of Social Sciences, İstanbul Sabahattin Zaim University, İstanbul, Turkey \\ ${ }^{2}$ Eğitim Fakültesi, İstanbul Sabahattin Zaim University, İstanbul, Turkey
}

Corresponding Author: Ayşenur Baysal, aysenurdayioglu@gmail.com

Article Type: Research Article

To Cite This Article: Baysal, A., \& Özgenel, M. (2019). Ortaokul öğrencilerinin bağlanma stilleri ve öz-düzenleme düzeyleri arasındaki ilişkinin incelenmesi. Eğitimde Kuram ve Uygulama, 15(2), 142-152 doi: 10.17244/eku.507650 


\title{
Ortaokul Öğrencilerinin Bağlanma Stilleri ve Öz-Düzenleme Düzeyleri Arasındaki İlişkinin İncelenmesi
}

\author{
Ayşenur Baysal $^{1}$, Mustafa Özgenel ${ }^{2}$ \\ ${ }^{1}$ Sosyal Bilimler Enstitüsü, İstanbul Sabahattin Zaim Üniversitesi, İstanbul, Türkiye \\ ORCID: http://orcid.org/ 0000-0001-6666-1125 \\ ${ }^{2}$ Ĕ̈itim Fakültesi, İstanbul Sabahattin Zaim Üniversitesi, İstanbul, Türkiye \\ ORCID: http://orcid.org/ 0000-0002-7276-4865
}

\begin{abstract}
Öz
Araştırmada, ortaokul öğrencilerinin bağlanma stilleri ile öz düzenleme düzeyleri arasındaki ilişkiyi incelemek amaçlanmıştır. Ayrıca bağlanma stilleri ve öz düzenleme düzeyleri cinsiyet, sınıf seviyesi ve okul türü değişkenlerine göre farklılık gösterip göstermediği ele alınmıştır. Araştırmada, nicel araştırma yöntemlerinden ilişkisel tarama modeli tercih edilmiştir. Araştırmanın çalışma grubunu İstanbul'un Üsküdar ilçesinde bulunan özel ve devlet ortaokullarında eğitim gören 205 kız, 169 erkek olmak üzere toplam 374 gönüllü öğrenci katılmıştır. Veriler Kişisel Bilgi Formu, Kerns Güvenli Bağlanma Ölçeği ve Algılanan Öz-düzenleme Ölçeği kullanılarak elde edilmiştir. Verilerin analizinde, bağımsız gruplar t- testi, tek yönlü varyans analizi (Anova) ve Pearson Momentler Çarpımı Korelasyonu kullanılmıştır. Yapılan analizler sonucunda, bağlanma stilleri ile öz düzenleme düzeyleri arasında pozitif yönde anlamlı ilişki bulunmuştur. Aynı zamanda bağlanma stilleri ve öz düzenleme düzeyleri cinsiyete, okul türüne ve sınıf seviyesine göre farklılaşmaktadır.
\end{abstract}

\section{Makale Bilgisi}

Anahtar Kelimeler:

Bağlanma, Bağlanma stilleri, Öz-düzenleme

Makale Geçmişi:

Geliș: 03 Ocak 2019

Düzeltme: 08 Şubat 2019

Kabul: 25 Şubat 2019

Makale Türü: Araştırma

Makalesi

\section{Investigation of the Relationship Between Secondary School Students' Attachment Styles and Self- Regulation Levels}

\footnotetext{
Abstract

In this study the aim was to investigate the relationship between secondary school students' attachment styles and self-regulation levels. The study also examined whether the attachment styles and self-regulation levels differed according to gender, class level and school type variables. In the study, a relational survey model was preferred from among quantitative research methods. The sample of the research consist of 205 female and 169 male students, a total of 374 volunteers from 5th, 6th, 7th and 8th grades, who were educated in private and state secondary schools located in the Üsküdar district of Istanbul. The data were collected using the Personal Information Form, the Kerns Secure Attachment Scale and the Perceived Self-Regression Scale. In the analysis of the data, an independent t-test, one way variance analysis (Anova) and Pearson Moments Multiplication Correlation were used. As a result of the analysis, there was a significant positive correlation between attachment styles and self-regulation levels. At the same time, attachment styles and self-regulation levels differed according to school types.
}

\section{Article Info}

Keywords: Attachment, Attachment styles, Selfregulation

\section{Article History:}

Received: 03 January 2019

Revised: 08 February 2019

Accepted: 25 February 2019

Article Type: Research Article 


\section{Giriş}

İnsan sosyal bir varlık olarak çevresindeki varlıklarla ilişki kurma ihtiyacı içindedir ve kendini sürekli güvende hissetmeyi ister. Kendine güven sağlayacak varlıklarla duygusal yakınlık kurar. Bu duygusal yakınlık bağlanma olarak adlandırılır. Bağlanma duygusunun önemli nedenlerinden biri de insanın hayatta kalabilmek için diğer canlılara ihtiyaç duymasıdır. Bağlanma bebek ile annesi veya bebeğin bakımını sağlayan kişi arasında oluşan ve temelinde güven duygusunun olduğu düşünülen bir duygudur (Güneş, 2014).

Çocuk gelişiminde, çocuğun anne ve babası veya bakımını üstlenen birey ile arasında oluşan bu bağ bireyin gelecek yaşamında onu etkileyen bir faktör olmaktadır (Tüzün \& Sayar, 2006). Bağlanma kavramı; anne, baba ve çocuk arasında oluşan yakınlığı açıklamak amacı ile ilk kez 1950-1960 yılları arasında John Bowlby (1958) tarafından ileri sürülmüştür. İlk altı ay civarında ortaya çıkan bağlanma davranışı çocukta bir yaş civarlarında gelişimini tamamlar (Bretherton, 1992). Bağlanmanın oluşması bebeklik yıllarında olsa da sonraki yıllarda da bağlanma oluşabilir ve bağlanılan figürlerde değişiklik olabilir. Bağlanma bireyin kişilik özellikleri, sosyal çevresi ve aile sistemi gibi değişkenlerden etkilenebilmektedir (Güneş, 2014). Literatür incelendiğinde bağlanma kavramı ile ilgili kuramcıların tanımlarının birbiriyle yakınlık gösterdiği görülmektedir. Gander ve Gardiner (1995) bağlanmayı yeni doğan bebekler ile onların ebeveynleri arasında oluşan ve yıllar geçtikçe kuvvetli hale gelen bir bağ olarak tanımlar. Bowlby (1969, 1973, 1979, 1980; akt. Sümer \& Güngör, 1999) bağlanmayı kişilerin kendisi için önemli olduğunu düşündükleri bireylere karşı geliştirdikleri duygusal bir yakınlık olarak ifade eder.

Bağlanmanın temelinde bireyin bazı ihtiyaçlarının karşılanması vardır ve bu sebeple bağlanma sadece çocuklukta olan ve biten bir durum değildir. Yetişkinlerinde karşılanması gereken bazı ihtiyaçları vardır. Bebeklik dönemindeki bağlanma tek yönlü iken yetişkinlikte bazı farklılıklar olmaktadır. İnsanlar yapı olarak kendilerini güvende hissetmek isterler ve bu yüzden kendileri için eş ve arkadaşlara ihtiyaç duyarlar. Bağlanmaya ihtiyaç duyan insanlar aynı zamanda birer bağlanma nesnesi de olmaktadırlar. Bu sebeple bağlanma artık tek yönlü bir durum olmaktan çıkmaktadır. Yetişkinlerin kendisi için bağlanma nesnesi olacak figürleri seçerken bebeklik döneminde yaşamış oldukları bağlanma stilleri etkili olmaktadır (Raja, 1991).

Bowlby (1958) ve Ainsworth (1989) yaptıkları çalışmalarda güvenli, kaygılı-kararsız ve kaçınan olmak üzere üç çeşit bağlanma stilinden bahsetmiştir. Bartholomew ve Horowitz (1991) ise Bowlby'nin çalışmalarını temel almış olmasına rağmen bu bağlanma stillerinden farklı olarak yetişkinlerde dörtlü bağlanma modelini geliştirmişlerdir. Bu modelde dört tür bağlanma stili, yer almaktadır. Bunlar: Güvenli, saplantıl1, kayıtsız, korkuludur (Altundağ, 2011).

Güvenli bağlanma stili, kişinin kendisi ve başkası hakkındaki algılarının olumlu olduğu stildir (Bowlby, 1958). Bu bağlanma stiline sahip kişiler hem kendileri ile ilgili gerçekçi kabullere sahiptirler hem de diğer kişilerle kolaylıkla sağl1klı bir iletişime geçebilirler. Küçük yaşlarda yaşanan güvenli bağlanma bireyin gelecek yaşamında meydana gelecek duygusal sorunların kolay çözülebileceği anlamına gelmektedir. Güvenli bağlanma stiline sahip bireylerin aile uyumunun yüksek olduğunu söylemek mümkündür (Güngör, 2000).

Kendilerini olumsuz değerlendirirken başkalarını olumlu değerlendiren bireylerin sahip olduğu bağlanma stili saplantılıdır (Bowlby, 1958). Bu bağlanma stiline sahip olan bireyler kendilerinin değerli olduğunu hissetmek için başkalarının düşüncelerini fazla önemserler. Genellikle insanların iyi olduğunu düşünürler ve ilişki kurma konusunda çekingen davranırlar. Kolaylıkla kabul görmeyeceklerini düşünürler ve reddedilme korkusu yaşarlar bu sebeple kişiler arası ilişkilerde pek sağlıklı değildirler (Sümer \& Güngör, 1999).

Kayıtsız bağlanma tarzı, saplantılı bağlanmada farklı olarak kişinin kendisine ait olumlu algıya sahipken, başkalarına ilişkin algının olumsuz olduğu bir stildir. Bu bağlanma stiline sahip olan bireyler yüksek öz saygıya sahiplerdir. Kendilerine çok fazla güvenip başkalarına karşı çok önyargıya sahip olabilirler. Bu sebeple yalnız kalma ihtimalleri fazladır. Aynı zamanda ilişkileri yakınlıktan uzak ve yüzeyseldir. Yakın ilişkilerden kaçınma sebepleri hayal kırıklığına uğramak istemeyişleri olabilmektedir (Bowlby, 2018).

Hem kendilerini hem de başkalarını olumsuz değerlendiren bireylerin sahip olduğu bağlanma stili korkuludur (Bowlby, 1958). Bu bağlanma stiline sahip olan bireyler kendilerine gereken güveni ve değeri vermedikleri gibi başkalarına karşı da şüphe ile yaklaşırlar. Başkaları tarafından kabul görmeyi isterler ancak kabul görme şüpheleri yüzünden uzak dururlar. Bu bağlanma stiline sahip bireylerin anne babalarını baskıcı ve otoriter olabilir. Korkulu 
bağlanma ile cinsiyet arasındaki ilişkiye bakıldığında kadınların erkeklere oranla daha çok bu bağlanma stiline sahip olduğu görülmüştür (Güneş, 2014).

Literatür incelendiğinde özellikle bebeklik dönemlerinde etkili olan ama yaşamın hemen her döneminde kendini gösteren bağlanma stillerinin iletişim becerileri (Kılıç, 2016), kimlik statüleri (Baş, 2013), öz yeterlilikleri (Erzen, 2013), karar verme stilleri (Yılmaz, 2015), stresle başa çıkma tutumları (Altundağ, 2011) ve sınav kaygıları (Erzen, 2013) ile arasındaki ilişkileri inceleyen çalışmalar bulunmaktadır. Bu çalışmada bağlanma stilleri ile kişilerin hayatlarında önemli olduğu düşünülen bir diğer kavram olan öz düzenleme düzeyi arasındaki ilişki incelenmiştir.

Akademik başarının en önemli faktörlerinden biri olarak kabul edilen öz-düzenleme farklı şekillerde tanımlanmıştır (Üredi ve Üredi, 2005). Bandura (1991) öz düzenlemeyi, "motivasyon, duygu, düşünce ve davranışın etkisi ile kişisel kimliğin gelişmesinde ana rol oynayan bir etkinlik mekanizması" olarak tanımlamıştır. Pintrich'e (2000) göre öz düzenleme öğrenme konularına, özellikle de okul veya sınıf bağlamlarında gerçekleşen akademik öğrenmeye uygulanmasıyla ilgilidir. Pintrich öz-düzenlemeyi "öğrencilerin öğrenme ile ilgili ideallerini belirledikleri, bilişsel süreçlerini, motivasyon durumlarını bunlara bağlı olarak davranışları üzerinde düzenleme yaptıkları, hedefler ve somut gözlenebilen özellikler tarafından sınırlandırılıp, yönlendirildikleri aktif ve taklip edici bir süreç" şeklinde tanımlamaktadır. Risemberg ve Zimmerman'a (1992) göre öz-düzenleme, öğrencilerin öğrenmelerini başlatmak, yönlendirmek ve izlemek için kullandıkları süreç ve stratejilerdir.

Öz düzenleme becerisi ile öğrenciler kendi duygu, düşünce ve davranışlarını kullanarak hedeflerine ulaşabilmekte; aynı zamanda kendisine uygun amaçlar belirleyip yeni stratejiler geliştirebilmektedir. Kısacası öz düzenleme öğrencinin öğrenme süreçlerinden kendisinin sorumlu olmasıdır. Bu sorumluluk bilincini kazanmış bireyler öğrenme süreçlerindeki eksikliklerinin farkında ve bu eksikliklerin nasıl giderileceğinin bilincinde olmaktadır (Yüksel 2003).

Literatürde öz düzenleme ile öğrenme becerisi (Baldan, 2017), motivasyon ve biliş üstü becerileri (Budak, 2016), akademik başarı düzeyi (Demircan, 2014), duygu kontrolü (Yıldız, Kara, Tanrıbuyurdu \& Gönen, 2014) arasındaki ilişkiyi inceleyen çalışmalar bulunmaktadır. Ancak literatür incelendiğinde bağlanma stilleri ve öz düzenleme düzeyleri arasındaki ilişkiyi incelen bir çalışmaya rastlanmamıştır. Bunula birlikte bireylerin bebeklik dönemlerinde başlayan ve yaşamının ilerleyen dönemlerinde de devam eden bağlanma stillerini (Yılmaz, 2015) etkileyen en önemli etkenlerden biri olarak aile kabul edilmektedir. Ayrıca Üredi ve Erden'e (2009) göre aileler çocuklarına öz-düzenleme konusunda rol model olmaktadır. $\mathrm{Bu}$ anlamda söz konusu bağlanma stilleri ve özdüzenleme kavramları teorik olarak birbiri ile ilişkili olduğu düşünülmüş ve ortaokul öğrencilerin bağlanma stilleri ile öz düzenleme düzeyleri arasında bir ilişki olup olmadığının araştırılmasına gerek duyulmuştur. Çalışmadan elde edilecek olan bulgular hem çocuklarını yetiştirecek olan ebeveynlerin daha bilinçli olması hem de bu ebeveynlere ortam hazırlayacak olan yetkililere, eğitimcilere ve psikolojik danışmanlara bağlanma stilleri ile öz düzenleme arasındaki ilişki hakkında 1şık tutacaktır. Bu bağlamda araştırmanın amacı ortaokul öğrencilerinin bağlanma stilleri ile öz düzenleme düzeyleri arasındaki ilişki olarak belirlenmiştir. Bu temel amaca ulaşmak için aşağıdaki sorulara yanıt aranmıştır:

1. Ortaokul öğrencilerinin bağlanma stilleri ve öz düzenleme düzeyleri cinsiyetlerine, okul türlerine ve sinıf seviyelerine göre anlamlı bir şekilde farklılaşmakta mıdır?

2. Ortaokul öğrencilerinin bağlanma stilleri ile öz düzenleme düzeyleri arasında anlamlı bir ilişki var mıdır?

\section{Araştırma Modeli}

\section{Yöntem}

Araştırmada, nicel araştırma yöntemlerinden ilişkisel tarama modeli tercih edilmiştir. Tarama yöntemi, bir gruba ait belirli özellikleri saptamak için verilerin toplanmasını hedefleyen çalışma yöntemidir. İlişkisel tarama modeli iki veya daha fazla değişken arasındaki ilişkileri belirlemeyi amaçlar (Büyüköztürk, 2017).

\section{Araştırmanın Çalışma Grubu}

Araştırmanın çalışma grubunu, 2017-2018 eğitim-öğretim y1lında İstanbul ili Üsküdar İlçesinde bulunan bir özel ve bir devlet okulunda eğitim gören 5., 6., 7. ve 8. Sınıf öğrencileri oluşturmaktadır. Bu öğrenciler kolay ulaşılabilir örneklem yöntemiyle seçilmiştir. Bu bağlamda, öğrencilere verilen 450 formdan geçersiz olanlar elemeden geçirildikten sonra, araştırma devlet okullarından 118, özel okullardan ise 256 olmak üzere toplam 374 öğrenci ile gerçekleştirilmiştir. 374 öğrenciden 205'i kız, 169'u erkek öğrencidir. Bu öğrencilerden 63'ü 5. sınıfta, 126's1 6.sınıfta, 97'si 7. Sınıfta, 88'i 8. sinıfta öğretim görmektedir. 


\section{Veri Toplama Araçları ve Verilerin Toplanması}

Araştırmanın yapılacak okulların okul müdürlerine ve psikolojik danışmanlarına uygulama hakkında bilgi verildi, uygulamanın hangi gün ve saatlerde hangi sınıflara yapılacağı belirlendi. Belirlenen gün ve ders saatlerinde, gönüllü olan öğrencilere araştırmacı tarafından ölçme araçları uygulanarak araştırma verilerine ulaşıldı. Veri toplamak amacıyla, Kerns Güvenli Bağlanma Ölçeği, Algılanan Öz-düzenleme Ölçeği ve kişisel bilgi formu kullanılmıştır.

Kişisel Bilgi Formu: Araştırmanın bağımsız değişkenlerine ilişsin veriler araştırmacı tarafından hazırlanan Kişisel Bilgi Formu ile elde edilmiştir. Kişisel Bilgi Formu ile cinsiyet, sınıf düzeyi ve okul türünü içeren değişkenler ile ilgili bilgiler saptanmıştır.

Kerns Güvenli Bağlanma Ölçeği: Ölçek Kerns ve arkadaşları (1996) tarafından geliştirilmiş, Sümer ve Şendağ (2009) tarafından Türkçe'ye uyarlanmıştır. 15 maddeden oluşan ölçek, çocukların ebeveynlere karşı duyduğu güvenli bağlanma düzeyini ölçmeyi amaçlamaktadır. Bu ölçekte her madde için karşıt yönlü iki ifade bulunmaktadır (Bazı çocuklar... ama Bazı çocuklar...). Katılımcılardan, öncelikle "AMA" yazan kutunun hemen sağında ve solunda tanımlanan iki çocuk tipinden hangisine daha çok benzediğine karar vermesi daha sonra da seçtiği tarafa gidip tarif edilen çocuğa ne kadar benzediğini ifade etmesi beklenmektedir. Ters yönde yazılmış yedi madde yeniden kodlandıktan sonra ölçek toplam puan üzerinden (15-60 arasında değişen puanlarla) ya da madde sayısına bölünerek ortalama değerler üzerinden (1-4 arasında değişen puanlarla) değerlendirilebilir. Yüksek puanlar ebeveynlere karş1 güvenli bağlanmaya karşılık gelmektedir. Ters kodlanan maddeler: 1, 3, 4, 9, 10, 13, 15'dir. Bu araştırmada ölçeğin güvenirlik katsayısı 0.84 olarak hesaplanmıştır.

Algılanan Öz-düzenleme Ölçeği: Bu ölçek 16 maddeden oluşmakta ve öğrencilerin öz-düzenleme düzeylerini ölçmeyi amaçlamaktadır. "Algılanan Öz-düzenleme Ölçeği” Arslan ve Gelişli (2015) tarafından geliştirilmiştir. Ölçme aracının değerlendirilmesi, "hiçbir zaman" ve "her zaman" uçları arasında belirlenen 5 dereceye göre gerçekleştirilmiştir. Ölçme aracı, açık olma ve arayış olmak üzere iki boyuttan oluşmaktadır. Algılanan Özdüzenleme Ölçeğinin Cronbach Alpha iç tutarlılık güvenirlik katsayıları açık olma alt ölçeği için 0.84 , arayış alt ölçeği için 0.82 ve ölçeğin tamamı için 0.90 olarak bulunmuştur. Ölçek maddeleri içinde ters kodlanan madde bulunmamaktadır. Ölçekten alınan puanlar yükseldikçe bireyin öz düzenleme becerisinin arttığı söylenebilir. Bu araştırmada güvenirlik katsayısı 0.85 olarak hesaplanmıştır.

\section{Verilerin Analizi}

Katılımcılardan elde edilen öz düzenleme, bağlanma stilleri ve demografik bilgi verileri öncelikle Microsoft Excel Worksheet programında geçirilip kaydedilmiştir. Daha sonra elde edilen dosya, SPSS 25.0 paket programına aktarılmıştır. Daha sonra ise katılımcıların öz düzenleme ve bağlanma stillerinin cinsiyete ve okul türüne göre farklılaşıp farklılaşmadığının belirlenmesi için bağımsız t test tekniği kullanılmıştır. Katılımcıların öz düzenleme ve bağlanma stillerinin sınıf seviyesine göre farklılaşıp farklılaşmadığını belirlemek için tek yönlü varyans analizi (Anova) tekniği kullanılmıştır. Son olarak da katılımcıların bağlanma stilleri ve öz düzenleme düzeyleri arasında anlamlı bir ilişki olup olmadığına Pearson Momentler Çarpımı Korelasyonu ile bakılmıştır. Sonuçların yazılımında 0.05 anlamlılık düzeyi ölçüt olarak alınmıştır.

\section{Bulgular}

$\mathrm{Bu}$ bölümde araştırmanın amacına uygun olarak yapılan analizlere yer verilmiştir. Öncelikle ortaokul öğrencilerinin bağlanma stilleri ve öz-düzenleme düzeylerinin cinsiyetlerine göre anlamlı bir farklılık gösterip göstermediğini belirlemek için yapılan t testi sonuçları Tablo 1'de verilmiştir.

Tablo 1. Cinsiyetlere göre bağlanma stilleri ile öz düzenleme düzeyinin karşılaştırılması

\begin{tabular}{|c|c|c|c|c|c|c|}
\hline & Cinsiyet & n & Ort. & SS & $\mathbf{t}$ & $\mathbf{p}$ \\
\hline \multirow{2}{*}{ Bağlanma Stili } & $\mathrm{K}_{1 \mathrm{Z}}$ & 205 & 46,970 & 8,179 & \multirow{2}{*}{1,079} & \multirow{2}{*}{,281 } \\
\hline & Erkek & 169 & 46,082 & 7,588 & & \\
\hline \multirow{2}{*}{ Açık olma } & $\mathrm{K} 1 \mathrm{Z}$ & 205 & 31,068 & 4,518 & \multirow{2}{*}{2,004} & \multirow{2}{*}{,046 } \\
\hline & Erkek & 169 & 30,112 & 4,676 & & \\
\hline \multirow{2}{*}{ Arayış } & $\mathrm{K} 1 \mathrm{z}$ & 205 & 28,307 & 6,167 & \multirow{2}{*}{,944 } & \multirow{2}{*}{,346 } \\
\hline & Erkek & 169 & 27,710 & 5,986 & & \\
\hline \multirow{2}{*}{ Öz düzenleme } & $\mathrm{K} 1 \mathrm{Z}$ & 205 & 59,35 & 9,60 & \multirow{2}{*}{1,54} & \multirow{2}{*}{, 122} \\
\hline & Erkek & 169 & 57,82 & 9,70 & & \\
\hline
\end{tabular}


Tablo 1 incelendiğinde ortaokul öğrencilerinin bağlanma stilleri $(\mathrm{t}=1,079 ; \mathrm{p}>.05)$, Öz düzenleme $(\mathrm{t}=1,549$; $\mathrm{p}>.05)$ ve öz düzenleme alt boyutlarından arayış $(\mathrm{t}=0,944 ; \mathrm{p}>.05)$ puan ortalamaları cinsiyete göre anlamlı bir farklılık göstermezken; açık olma puan ortalamalarına bakıldığında erkek öğrencilerin puan ortalaması $\overline{\mathrm{x}}=30.1$ iken kızlarda bu değer $\bar{x}=31.06$ 'dir. Açık olma alt boyutu anlamlı düzeyde farklılık göstermektedir ( $t=2,004, p<.046)$. Kız öğrencilerin açık olma puanlarının erkek öğrencilerin açık olma puanlarına göre anlamlı düzeyde daha yüksek olduğu belirlenmiştir.

Ortaokul öğrencilerinin bağlanma stilleri ve öz-düzenleme düzeylerinin okul türüne göre anlamlı bir farklılık gösterip göstermediğini belirlemek için yapılan t testi sonuçları Tablo 2'de verilmiştir.

Tablo 2. Okul türüne göre bağlanma stilleri ile öz düzenleme düzeylerinin karşılaştırılması

\begin{tabular}{|c|c|c|c|c|c|c|}
\hline & Okul türü & $\mathbf{n}$ & Ortalama & SS & $\mathbf{t}$ & p \\
\hline \multirow{2}{*}{ Bağlanma Stili } & Özel & 256 & 45,714 & 8,080 & \multirow{2}{*}{$-3,109$} & \multirow{2}{*}{,002 } \\
\hline & Devlet & 118 & 48,423 & 7,254 & & \\
\hline \multirow{2}{*}{ Açık olma } & Özel & 256 & 30,128 & 4,572 & \multirow{2}{*}{$-3,174$} & \multirow{2}{*}{,002 } \\
\hline & Devlet & 118 & 31,737 & 4,514 & & \\
\hline \multirow{2}{*}{ Arayış } & Özel & 256 & 27,378 & 6,080 & \multirow{2}{*}{$-3,118$} & \multirow{2}{*}{,002 } \\
\hline & Devlet & 118 & 29,466 & 5,871 & & \\
\hline \multirow{2}{*}{ Öz düzenleme } & Özel & 256 & 57,507 & 9,631 & \multirow{2}{*}{$-3,487$} & \multirow{2}{*}{,001 } \\
\hline & Devlet & 118 & 61,203 & 9,287 & & \\
\hline
\end{tabular}

Tablo 2 incelendiğinde ortaokul öğrencilerinin bağlanma stilleri $(\mathrm{t}=3.109 ; \mathrm{p}<.05)$, öz düzenleme ( $\mathrm{t}=3.487$; $\mathrm{p}<.05)$ ve öz düzenleme alt boyutlarından arayış $(\mathrm{t}=3.118 ; \mathrm{p}<.05)$ ve açık olma $(\mathrm{t}=3.174 ; \mathrm{p}<0.05)$ puan ortalamaları okul türüne göre anlamlı bir farklılık göstermektedir. Grup ortalamalarına bakıldığında bu anlamlı farklılığın devlet okulunda eğitim gören öğrencilerin bağlanma stillerinin $(\overline{\mathrm{X}}=48.42)$ özel okulda eğitim gören öğrencilerden $(\overline{\mathrm{X}}=45.79)$ anlamlı düzeyde yüksek olduğu görülmektedir.

Ortaokul öğrencilerinin bağlanma stilleri ve öz-düzenleme düzeylerinin sınıf seviyesine göre anlamlı bir farkl11ık gösterip göstermediğini belirlemek için yapılan t testi sonuçları Tablo 3’te verilmiştir.

Tablo 3. Öğrencilerin sınıf seviyelerine göre bağlanma stilleri ve öz düzenleme düzeylerinin karşılaştırılması

\begin{tabular}{|c|c|c|c|c|c|c|c|c|c|c|c|}
\hline & Sinıf & $\mathbf{N}$ & $\mathbf{X}$ & Ss & $\begin{array}{l}\text { Varyansın } \\
\text { Kaynağı }\end{array}$ & KT & sd & KO & $\mathbf{F}$ & $\mathbf{p}$ & Anlamlılık \\
\hline \multirow{5}{*}{ 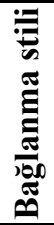 } & 5. Sinif & 63 & 48,127 & 7,04 & G. Aras1 & 504,25 & 3 & 168,08 & \multirow{5}{*}{2,717} & \multirow{5}{*}{,045 } & \multirow{5}{*}{$\begin{array}{c}5-8 \\
6-8\end{array}$} \\
\hline & 6. Sinif & 126 & 47,246 & 8,27 & G. İçi & 22893,43 & 370 & 61,87 & & & \\
\hline & 7.Sinıf & 97 & 46,319 & 7,23 & Toplam & 23397,69 & 373 & & & & \\
\hline & 8. Sinif & 88 & 44,761 & 8,47 & & & & & & & \\
\hline & Toplam & 374 & 46,569 & 7,92 & & & & & & & \\
\hline \multirow{5}{*}{$\begin{array}{l}\text { 音 } \\
0 \\
\frac{y}{2}\end{array}$} & 5. Sinıf & 63 & 30,190 & 4,77 & G. Arası & 50,73 & 3 & 16,91 & \multirow{5}{*}{,795 } & \multirow{5}{*}{,497 } & \\
\hline & 6. Sinif & 126 & 31,047 & 4,82 & G. İçi & 7873,80 & 370 & 21,28 & & & \\
\hline & 7.Sinıf & 97 & 30,247 & 4,31 & Toplam & 7924,54 & 373 & & & & \\
\hline & 8. Sinıf & 88 & 30,795 & 4,50 & & & & & & & \\
\hline & Toplam & 374 & 30,636 & 4,60 & & & & & & & \\
\hline \multirow{5}{*}{ 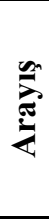 } & 5. Sinıf & 63 & 28,190 & 5,93 & G. Aras1 & 279,36 & 3 & 93,12 & \multirow{5}{*}{2,546} & \multirow{5}{*}{,056 } & \\
\hline & 6. Sinıf & 126 & 29,150 & 5,98 & G. İçi & 13534,11 & 370 & 36,57 & & & \\
\hline & 7.Sinıf & 97 & 27,195 & 5,92 & Toplam & 13813,47 & 373 & & & & \\
\hline & 8. Sinıf & 88 & 27,261 & 6,34 & & & & & & & \\
\hline & Toplam & 374 & 28,037 & 6,08 & & & & & & & \\
\hline \multirow{5}{*}{ 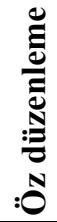 } & 5. Sinıf & 63 & 58,381 & 9,61 & G. Aras1 & 478,65 & 3 & 159,55 & \multirow{5}{*}{1,718} & \multirow{5}{*}{, 163} & \\
\hline & 6. Sinif & 126 & 60,198 & 9,83 & G. İçi & 34369,55 & 370 & 92,89 & & & \\
\hline & 7.Sinıf & 97 & 57,443 & 9,23 & Toplam & 34848,20 & 373 & & & & \\
\hline & 8. Sinıf & 88 & 58,056 & 9,80 & & & & & & & \\
\hline & Toplam & 374 & 58,673 & 9,66 & & & & & & & \\
\hline
\end{tabular}

Tablo 3'te ortaokul öğrencilerinin bağlanma stilleri, öz düzenleme düzeyleri ile açık olma ve arayış alt boyutlarının sınıf seviyesi değişkenine göre anlamlı bir şekilde farklılaşıp farklılaşmadığını belirlemek üzere tek yönlü varyans analizi (ANOVA) yapılmıştır. Yapılan analiz sonucunda sınıf seviyelerine göre ortaokul öğrencilerinin bağlanma stilleri toplam puanı istatistiksel açıdan anlamlı bir şekilde farklılaşmaktadır $(\mathrm{p}<0.05)$. Bu anlamlı farklılık 
5. $\sin 1 f(\bar{X}=48.12)$ ile 8. sinif $(\bar{X}=44.76)$ ve 6. sinif $(\bar{X}=47.24)$ ile 8. $\sin 1 f(\bar{X}=44.76)$ grupları arasindadir. 5. ve 6. sinif öğrencilerin güvenli bağlanma düzeyleri 8. sınıf öğrencilerin güvenli bağlanma düzeylerinden yüksektir. Ortaokul öğrencilerinin sınıf düzeyine göre öz düzenleme düzeyleri $(\mathrm{p}=1.718>0.05)$ ve öz düzenleme alt boyutları arayış $(\mathrm{p}>0.05)$ ve açık olma $(\mathrm{p}>0.05)$ puanları arasında anlamlı bir farklılık yoktur.

Ortaokul öğrencilerinin öz düzenleme düzeyleri ile bağlanma stilleri arasındaki ilişkinin incelendiği korelasyon analizi sonuçları Tablo 4'te verilmiştir.

Tablo 4. Öğrencilerinin öz düzenleme düzeyleri ile bağlanma stilleri arasındaki korelasyon

\begin{tabular}{lccc}
\hline & BS & Açılk olma & Arayı̧̧ \\
\hline Bağlanma Stili & 1 & & \\
Açık Olma & $.226^{* *}$ & 1 & \\
Arayış & $.205^{* *}$ & $.627^{* *}$ & 1 \\
Öz düzenleme & $.237^{* *}$ & $.871^{* *}$ & $.928^{* *}$ \\
\hline
\end{tabular}

Tablo 4'de görüldüğü gibi öz düzenleme ve alt boyutları açık olma ve arayış ile "bağlanma stilleri" arasındaki karşılıklı ilişkiyi belirlemek üzere yapılan Pearson Momentler Çarpımı Korelasyonu Analizi sonucunda; ortaokul öğrencilerinin bağlanma stilleri ile öz düzenleme düzeyleri arasında pozitif yönde ve düşük düzeyde ( $\mathrm{r}=.24)$; bağlanma stilleri ile açık olma alt boyutu arasında pozitif yönde ve düşük düzeyde ( $\mathrm{r}=.23)$, bağlanma stilleri ile arayış alt boyutu arasında pozitif yönde ve düşük düzeyde anlamlı (r=21) bir ilişki bulunmaktadır.

\section{Sonuç, Tartışma ve Öneriler}

$\mathrm{Bu}$ araştırma ortaokul öğrencilerinin bağlanma stilleri ile öz düzenleme düzeyleri arasındaki ilişkiyi incelemek üzere gerçekleştirilmiştir. Aynı zamanda, bu araştırmada ortaokul öğrencilerinin bağlanma stillerinin ve öz düzenleme düzeylerinin cinsiyet, okul türü ve sınıf seviyesi durumuna göre farklılaşıp farklılaşmadığının tespit edilmesi amaçlanmıştır.

Ortaokul öğrencilerinin bağlanma stilleri, öz düzenleme ve alt boyutlarından arayış cinsiyete göre anlamlı bir şekilde farklılaşmazken; öz düzenleme alt boyutlarından açık olma anlamlı bir şekilde farklılaşmaktadır. Kız öğrencilerin açık olma puanlarının erkek öğrencilerin açık olma puanlarına göre anlamlı düzeyde daha yüksektir. Dadlı (2015) ortaokul 8. Sınıf öğrencilerinin fen ve teknoloji dersine yönelik öz düzenleme becerileri ile ilgili yapmış olduğu çalışmada kız öğrencilerin erkek öğrencilere göre daha yüksek öz düzenleme becerilerine sahip olduğunu tespit etmiştir. Bu yaş grubunda kız öğrencilerin daha çok akademik çalışmalara yöneldiği erkek öğrencilerin ise daha çok sosyal etkinliklere yöneldiği için bu farkl1lı̆̆ın ortaya çıkabileceği düşünülmektedir. Literatür incelendiğinde konu ile ilgili paralel bulgular olsa da farklı bulgulara da rastlanmıştır. Üredi ve Üredi (2005) yaptıkları bir çalışmada özdüzenleme stratejileri ve motivasyonel inançların matematik başarısını yordama gücünün erkek öğrencilerde kız öğrencilere göre daha yüksek olduğunu ifade etmiştir. Araştırmada bağlanma stillerinin cinsiyete göre anlamlı bir şekilde farklılaşmadığı görülmüştür. Bunun sebebinin bu yaşlarda ki öğrencilerin ilgilerini anne babalarından ziyade akranlarına yöneltmesi ve onlarla daha güçlü bağlar kurması şeklinde olduğu düşünülmektedir. Yolalan (2013) tarafından yapılan çalışmada kızların güvenli bağlanma ortalamasının erkeklere oranla daha düşük olduğunu yani erkeklerin kızlara göre daha güvenli bağlandığını bunun sebebinin ise erkeklerin kızlara göre ebeveynlerinden daha tutarlı ve ilgili bir yaklaşım görmesi olabileceğini ifade etmiştir.

Ortaokul öğrencilerinin bağlanma stilleri, öz düzenleme ve öz düzenleme alt boyutlarından arayış ve açık olma okul türüne göre anlamlı bir farklılık göstermektedir. Devlet okulunda eğitim gören öğrencilerin bağlanma stilleri özel okulda eğitim gören öğrencilerden anlamlı düzeyde yüksektir. Bu farklılığın özel okulda eğitim gören öğrencilerin ailelerinin maddi olarak daha büyük bir yükümlülügün altında olmasından bu yüzden anne ve babanın daha çok çalışması gerektiğinden kaynaklandığı düşünülmektedir. Bu durumda özel okul ile devlet okullarının öğrenci yapısının incelenmesi gerekli ise de iki kurum arasındaki farklılıklar özellikle aile yaşamı konusunda kendini göstermektedir. Özel okulların hitap ettiği kesim ile devlet okullarının hitap ettiği kesim arasındaki temel farklılığın ekonomik gelişim olduğu aşikârdır. Bunun haricinde eğitim ve sosyal hayat boyutunda birbirinden farklılık göstermesi 
sadece maddi sebeplerin etkili olmadığını göstermektedir. Özel okullardaki öğrencilerin aileleri ile geçirdikleri vakit ve geçirilen vaktin kalitesi ile ailelerin bireye bakış açıları bu farklılığın özünü oluşturmaktadır.

Sınıf seviyelerine göre ortaokul öğrencilerinin bağlanma stilleri anlamlı bir şekilde farklılaşmaktadır. Bu anlamlı farklı1ık 5. sınıf ile 8. sınıf, 6. sınıf ile 8. sınıf grupları arasındadır. Sınıf seviyesi arttıkça çocukların bağ kurdukları kişi sayısı artmaktadır. Yaşları büyüdükçe çocuklar yakın arkadaşlarına ya da karşı cinsten kişilere bağlanabilmektedir. Bu sebeple anne veya baba ile kurulan bağın azaldığı düşünülmektedir. Araştırmada ortaokul öğrencilerinin sınıf düzeyine göre öz düzenleme düzeyleri ve öz düzenleme alt boyutları arayış ve açık olma arasında anlamlı bir farklılık yoktur. Bunun sebebinin öğrencilerin ilkokuldan sonra farklı bir eğitim kademesine geçmenin vermiş olduğu heyecan ve bazen de kaygı ile ortaokulun ilk yıllarında derslerine önem verdiği son yıllarında ise liseler için gireceği sınavlar nedeniyle aynı şekilde derslerini önemsediği şeklinde olduğu düşünülmektedir.

Yapılan araştırmada ortaokul öğrencilerinin bağlanma stilleri ile öz düzenleme ve öz düzenleme alt boyutları olan açık olma ve arayış arasında pozitif yönde ve düşük düzeyde anlamlı ilişki olduğu görülmüştür. Literatür incelendiğinde bağlanma stillerinin iletişim becerileri (Kılıç, 2016), kimlik statüleri (Baş, 2013), öz yeterlilikleri (Erzen, 2013), karar verme stilleri (Yılmaz, 2015), stresle başa çıkma tutumları (Altundağ, 2011) ve sınav kaygıları (Erzen, 2013) ile arasındaki ilişkileri inceleyen çalışmalar bulunmaktadır. Ancak bağlanma stilleri ve öz düzenlemeye ilişkin bir çalışmaya rastlanılmamıştır. Bu bağlamda elde edilen bulgular ışığında ortaokul öğrencilerinin güvenli bağlanma düzeyleri arttıkça öz düzenleme düzeyinde artış olduğu veya öz düzenleme düzeyi azaldıkça güvenli bağlanma düzeylerinin de azaldığı görülmektedir. Güvenli bağlanan bireylerin kendilerine ve başkalarına dair algıları olumludur. Aile ilişkileri daha kuvvetlidir. Kendisinin daha çok farkındadırlar bu yüzden kendilerini daha kolay motive edebilir ve düzenleyebilirler böylece öğrenme sürecine aktif katılım sağlayabilirler. Dolayısıyla bu bireylerin bulundukları ortamlara katılımları özellikle eğitim öğretime tutumları da olumludur. Eğitimin temel kurumu olan ailede hayata dair bilgileri reddetmek yerine sorgulayarak kabul etme eğilimleri daha gelişmiştir. Öğretimin temel noktası olan kurumlarda öğreticiye yönelik tepkileri de benzer şekilde kabul edici olacağından güvenli bağlanma stiline sahip olan bireylerin öz düzenleme düzeylerinin de artması beklenebilir.

Araştırmanın sonuçlarının tekrarlanabilirliğinin test edilebilmesi için farklı ve daha büyük örneklem gruplarıyla yeni araştırmalar yapılabilir. Araştırmada bağlanma stilleri ile öz düzenleme düzeyi arasında pozitif yönde düşükte olsa bir ilişki tespit edilmiştir. Buna dayanarak, anne veya baba ile kurulan bağın önemine dair ebeveynlere bilinçlendirme eğitimi verilebilir. 


\section{Extended Summary}

\section{Introduction}

A person who is a social being wants to have close relationships with other individuals and to trust them. This established proximity is called attachment. The concept of attachment is important for human survival and emotional intimacy with other people. This bond, established during infancy, affects the individual throughout his life.

There are four types of attachment styles: safe, obsessive, indifferent and fearful. In the style of safe attachment, the person's perception of himself or herself is positive. In the obsessive attachment style, the person's perception of himself / herself is negative, while the perception of others is positive. In the style of indifferent attachment, the person's perception of himself / herself is positive and his / her perception of others is negative. The person's perception of himself and others is negative in the style of fearful attachment.

The concept of self-regulation is defined by Bandura (1991) as 'an activity mechanism that plays a major role in the development of personal identity by the influence of motivation, emotion, thought and behavior. With selfregulation skills, the student will be responsible for his / her own learning processes.

In the secondary school (grades 5, 6, 7 and 8), which educates the young people who will guide the course of our country in the near future, self-regulation is very important for students when studying, because in this period more regular course work is required to enter the exam process. This examination will determine which high schools students can register for. As a result of these exams, they will study at a university depending on the high school they went to, they will choose a profession and live their lives in this framework. For this reason, it is necessary to investigate whether there is a relationship between the attachment styles and the self-regulation levels of secondary school students. The findings from the study will shed light on the relationship between self-regulation and the styles of attachment with regard to authorities, educators and psychological counsellors who will prepare the environment for the children as well as the parents who will raise their children. In this context, the purpose of the research was determined as the relationship between the attachment styles and the self-regulation levels of secondary school students. To achieve this basic goal, the following questions are asked:

1. Do the attachment styles and self-regulation levels of secondary school students differ significantly according to their gender, school types and class levels?

2. Is there a significant correlation between students' attachment styles and self-regulation levels?

\section{Method}

In this study, the relational scanning model was chosen from amongst quantitative research methods. The study was conducted in a private and a public school in Üsküdar, Istanbul, in the 2017-28 academic year. The students constitute classes 5, 6, 7 and 8 . These students were chosen by means of an easily accessible sampling method. The study was carried out with 374 students, 118 of which were from public schools and 256 from private schools. The school principals and psychological counsellors of the schools to be surveyed were informed about the application and the dates and times of the application were determined. At the specified dates and times, the research data was obtained by the researcher by applying the measurement tools to the students who were volunteers. In order to collect the data, Kerns Secure Attachment Scale, a Perceived Self-regulation Scale and a personal data form were used. The selfregulation, attachment styles, and demographic information data obtained from the participants were recorded in a Microsoft Excel Worksheet. Then the resulting file was transferred to the SPSS 25.0 package program. After that, the independent $t$ test technique was used to determine whether the participants' self-regulation and attachment styles were different according to gender and school type. The one-way variance analysis (Anova) technique was used to determine whether the participants' self-regulation and attachment styles differed according to class level. Finally, the a Pearson moments multiplication correlation analysis was conducted to examine whether there was a significant correlation between the bonding styles and self-regulation levels of the participants. For the results, the significance level of 0.05 was taken as a criterion. 


\section{Findings}

According to the findings obtained from the research conducted in order to examine the relationship between the attachment styles and self-regulation levels of secondary school students, the results can be summarized as follows:

While attachment styles, self-regulation and sub-dimensions of secondary school students did not differ significantly according to gender, the self-regulation sub-dimension of 'being open' differed significantly. The scores of female students are significantly higher than those of male students. The attachment styles, self-regulation and selfregulation sub-dimensions of secondary school students showed a significant difference according to school type. The scores for attachment styles of the students attending the public school were significantly higher than those for the students in private schools.

The attachment styles of secondary school students differed significantly in terms of class levels. These differences are between the 5th class and 8th class, and the 6th class and 8th class groups. In the study, it was seen that there was a positive and low level significant relationship between the attachment styles of secondary school students and self-regulation and the self-regulation sub-dimensions of 'being open' and 'searching'.

\section{Discussion and Conclusion}

The following recommendations can be made as a result of the research. In order to test the reproducibility of the results of the research, new studies can be carried out with different and larger sample groups. In the study, there was a positive and low correlation between attachment styles and the self-regulation level. On the basis of this, parents may be given training on the importance of the attachment to the mother or father. 


\section{Kaynakça / References}

Altundağ, G. (2011). Üniversite öğrencilerinde bağlanma stilleri, stresle başa çıkma tutumlarl ve stresi algılama düzeyinin incelenmesi (Yüksek Lisans Tezi). Haliç Üniversitesi, İstanbul.

Arslan, S. \& Gelişli, Y. (2015). Algılanan Öz-Düzenleme Ölçeği: Bir ölçek geliştirme çalışması. Sakarya University Journal of Education, 5(3), 67-74.

Baldan, B. (2017). Lisans öğrencilerinin öz düzenlemeli öğrenme becerisi düzeyleri ve yükseköğretim programlarının öz düzenlemeli ögrenme becerisini geliştirmedeki rolü (Yüksek Lisans Tezi). Anadolu Üniversitesi, Eskişehir.

Bandura, A. (1991). Social cognitive theory of self-regulation. Organizational Behavior And Human Decision Processes, 50(2), 248-287.

Bartholomew, K. \& Horowitz, L. M. (1991). Attachment styles among young adults: a test of a four-category model. Journal of Personality and Social Psychology, 61(2), 220-228.

Baş, N. (2013). Ergenlerin bağlanma stilleri ve kimlik statüleri arasındaki ilişskinin incelenmesi (Yüksek Lisans Tezi). Çukurova Üniversitesi, Ankara.

Bowlby, J. (1958). The nature of the child's tie to his mother. International Journal of Psycho- Analysis, 39, 350-373.

Bowlby, J. (1969). Attachment and loss: Attachment. New York: Basic Books.

Bowlby, J. (1973). Attachment and loss: Separation, anxiety and anger. New York: Basic Books.

Bowlby, J. (1979). The making and breaking of affectional bonds. London: Tavistock.

Bowlby, J. (1980). Attachment and loss: Sadness and depression. New York: Basic Books

Bowlby, J. (2018). Bă̆lanma (Çev: T. V. Soylu). İstanbul: Pinhan.

Bretherton, I. (1992). The origins of attachment theory: John Bowlby and Mary Ainsworth. Developmental Psychology, 28(5), $750-760$.

Budak, H. (2016). Illkokul dördüncü sinıf öğrencilerinin öz düzenleme, motivasyon, biliş üstü becerileri ve matematik dersi başarılarının belirlenmesi (Yüksek Lisans Tezi). Çanakkale Onsekiz Mart Üniversitesi, Çanakkale.

Büyüköztürk, Ş (2017). Bilimsel araştırma yöntemi. Pegem Akademi.

Dadlı, G.(2015). Ortaokul 8. Sinıf ögrencilerinin fen ve teknoloji dersine yönelik öz düzenleme becerileri ve öz yeterlilikleri ile akademik başarıları arasındaki ilişskinin incelenmesi (Yüksek Lisans Tezi). Kahramanmaraş Sütçü İmam Üniversitesi, Kahramanmaraş.

Demircan, Y. S. \& Tanrıseven, I. (2014). 5. sınıf öğrencilerinin sınıf içi etkinlik ve akademik başarı düzeylerine göre özdüzenleme stratejileri ve motivasyonel inançlarının incelenmesi. Journal of International Social Research, 7(35), 515530.

Erwin, P. (2000). Çocuklukta ve ergenlikte arkadaşlık. İstanbul: Alfa Basım Dağıtım.

Erzen, E. (2013). Üniversite sinavlarına hazırlanan ergenlerin bağlanma stilleri ve öz yeterlikleri ile sinav kayglları arasındaki ilişkinin incelenmesi (Yüksek Lisans Tezi). Karadeniz Teknik Üniversitesi, Trabzon.

Güneş, A. (2014). Güvenli bağlanma. İstanbul: Timaş Yayınları.

Güngör, D.(2000). Bağlanma stillerinin ve zihinsel modellerin kuşaklararası aktarımında ana babalık stillerinin rolü (Doktora Tezi). Ankara Üniversitesi, Ankara.

Kılıç, T. \& Kümbetlioğlu, M. (2016). Bağlanma stillerinin iletişim becerilerine etkisini araştırma. Çukurova Üniversitesi Sosyal Bilimler Enstitüsü Dergisi, 25(3), 381-396.

Pintrich, P. R. (2000). The role of goal orientation in self-regulated learning. In M. Boekaerts, P. R. Pintrich, \& M. Zeidner (Eds.), Handbook of self-regulation (pp. 451-502). San Diego, CA, US: Academic Press.

Raja, N. (1991). Perceived attachments to parents and peers well-being in adolescence, New York: Youth Adolesc.

Risemberg, R. \& Zimmerman, B. J. (1992). Self regulated learning in gifted students. Roeper Review, 15(2), 98-101.

Süer, N. (2014). Öz düzenleme becerilerinin TEOG slnavı üzerindeki etkisi (Yüksek lisans tezi). Yıldız Teknik Üniversitesi, İstanbul.

Sümer, N. \& Güngör, D. (1999). Psychometric evaluation of adult attachment measures on Turkish samples and a cross-cultural comparison. Türk Psikoloji Dergisi, 14(43), 71-109.

Sümer, N. \& Şendağ, M. A. (2009). Orta Çocukluk Döneminde Ebeveynlere Bağlanma, Benlik Algısı ve Kaygı. Türk Psikoloji Dergisi, 24(63), 86-101.

Tüzün, O. \& Sayar, K. (2006). Bağlanma kuramı ve psikopatoloji. Düşünen Adam, 19(1), 24-39.

Üredi, I. \& Erden, M. (2009). Öz-düzenleme stratejileri ve motivasyonel inançlarının yordayıcısı olarak algılanan anne baba tutumları. Türk Eğitim Bilimleri Dergisi, 7(4), 781-811.

Üredi, I. \& Üredi, L. (2005). İlköğretim 8. sınıf öğrencilerinin öz-düzenleme stratejileri ve motivasyonel inançlarının matematik başarısını yordama gücü. Mersin Üniversitesi Eğitim Fakültesi Dergisi, 1(2), 250-260. 
Baysal \& Özgenel

Yıldız, T. G., Kara, H. G. E., Tanrıbuyurdu, E. F., \& Gönen, M. (2014). Öz düzenleme becerilerinin öğretmen çocuk etkileşiminin niteliğine göre incelenmesi. Eğitim ve Bilim, 39(176).

Yılmaz, E. (2015). Ortaokul ögrencilerinin bă̆lanma stilleri ile karar verme stilleri arasındaki ilişkinin incelenmesi (Yüksek Lisans Tezi). Nişantaşı Üniversitesi, İstanbul.

Yolalan, H. (2013). Ergenlerde depresyon ve bağlanma stilleri arasındaki ilişkinin incelenmesi (Yüksek Lisans Tezi). Arel Üniversitesi, İstanbul.

Yüksel, G. (2003). İlköğretim öğrencilerinin gelişim alanları, gelişim alanlarının işaretçisi olan ihtiyaçlar ve geliştirilmesi gereken beceriler; bu süreçte rehber öğretmenin işlevleri: kurumsal bir inceleme. Milli Eğitim Dergisi, 159(3). 